\title{
PHARMACOGNOSTIC STANDARDIZATION OF STEMS OF VANDA ROXBURGHII ROXB.
}

\begin{abstract}
HAYAT M MUKHTAR ${ }^{1}$, VANDNA KALSI ${ }^{2,3 *}$
${ }^{1}$ Department of Pharmacy, Shaheed Bhagat Singh College of Pharmacy, Patti, Punjab, India. ${ }^{2}$ Department of Pharmaceutical Sciences, Lovely Professional University, Phagwara, Punjab, India. ${ }^{3}$ Department of Pharmaceutical Sciences, IKG Punjab Technical University,
\end{abstract} Kapurthala, Punjab, India. Email: vandana.kalsi@lpu.co.in

Received: 15 September 2017, Revised and Accepted: 20 November 2017

\section{ABSTRACT}

Objective: There is an expanding demand of herbal medicines due to their compelling and more secure method for treating different diseases. In the present situation, these drugs are much productive for the treatment of different issues as they have negligible reactions in contrast with the allopathic pharmaceuticals. Vanda roxburghii is an epiphytic plant that finds a mention in the indigenous systems of medicines such as Ayurveda and Unani and has been used traditionally in Bangladesh. In the present investigation, various pharmacognostic standards have been investigated to prove the authenticity of the plant for the claimed traditional uses.

Methods: The powdered drug was used for estimating the loss on drying, volatile oil content, ash values, fluorescence studies, extractive values, and phytochemical screening. Macroscopic and microscopic studies were also conducted on the powdered drug.

Results: Phytochemical screening has shown the presence of various phytoconstituents such as glycosides, alkaloids, polyphenols, tannins, steroids, flavonoids, resins, and carbohydrates.

Conclusion: $V$. roxburghii has been found to be useful as aphrodisiac, antibacterial, antifungal, antiulcer, anticonvulsant, and antioxidant agent. The present study provides the information on pharmacognostic characteristics, phytochemical screening, and physicochemical parameters.

Keywords: Vanda roxburghii, Orchidaceae, Phytochemical screening, Epiphytic.

(C) 2018 The Authors. Published by Innovare Academic Sciences Pvt Ltd. This is an open access article under the CC BY license (http://creativecommons. org/licenses/by/4. 0/) DOI: http://dx.doi.org/10.22159/ajpcr.2018.v11i2.22603

\section{INTRODUCTION}

Vanda roxburghii Roxb. (Synonym - Vanda tessellata) is a medicinal epiphytic perennial plant from family Orchidaceae found in the Indian subcontinent [1]. The plant is commonly known as Rasna [2]. Orchids are the biggest and the most differing bunch among the angiosperms. They are developed for delightful blossoms [3]. Ayurveda and Unani practitioners have used different parts of the plant for the treatment of various ailments. Various parts of this plant have been used in hiccough, piles and boils on the scalp, secondary syphilis, and scorpion sting [1]. The plant has been utilized as antipyretic, sexual stimulant, alexiteric, and also in inflammation, bronchitis, rheumatism, and in nervous disorders [4]. The plant also forms an ingredient of an ayurvedic formulation Rasna Panchaka Quatha, which is used in the treatment of arthritis and rheumatism. The roots are used as antidote against scorpion sting and as a remedy for bronchitis [5]. In Bangladesh, the roots of the plant have been used as brain tonic and in the treatment of nervous system disorders including Alzheimer's disease [6]. Important constituents of the plant are alkaloids, glycosides, bitter principles, tannins, resins, saponins, sitosterols, and coloring matter. The plant has been screened for various biological activities and has given productive outcomes. V. roxburghii has been observed to be valuable as antibacterial, antifungal, antiulcer, anticonvulsant, and cell reinforcement specialist. The plant has additionally been tried for hepatoprotective, mitigating, wound healing, antinociceptive, pain relieving, and antidiabetic properties [7].

Geographical source

The plant is widely distributed in tropical Asiatic and Australian zones (Fig. 1). It is found in West Bengal, Bihar, Central Provinces, and West Peninsula [8].
Taxonomical classification [9]

\begin{tabular}{ll}
\hline Kingdom & Plantae \\
\hline Subkingdom & Tracheobionta \\
Superdivision & Spermatophyta \\
Division & Magnoliophyta \\
Class & Liliopsida \\
Order & Orchidales \\
Family & Orchidaceae \\
Genus & Vanda \\
Species & Roxburghii \\
\hline
\end{tabular}

Synonyms [10]

\begin{tabular}{ll}
\hline Language & Common names of drug \\
\hline Sanskrit & Rasna, Vandaka \\
Bengali & Rasna \\
Gujarati & Rasna \\
Hindi & Vanda \\
Kannada & Banda Nike \\
Telugu & Van Danika \\
\hline
\end{tabular}

Macroscopic characters

The stems of the plant are climbing in nature, woody, stout, and give out many thick fleshy roots. Stems are 1-2 m long and cylindrical having distinct nodes and internodes [10].

\section{METHODS}

The stems of V. roxburghii were purchased from Burdwan Eco Garden, Kolkata, West Bengal, India, and identified by Dr. Ambarish Mukherjee, Centre for Advanced Study, Department of Botany, The University of Burdwan, Golapbag, Burdwan. The stems were washed thoroughly with 
tap water, then shade dried, homogenized to fine powder, and stored in airtight bottles.

Transverse section (TS) of the stem was cut to study its histological characters. Powdered drug was used for the determination of moisture content, volatile oil content, and ash values, and fluorescence studies were conducted by treating the powdered drug $(0.5 \mathrm{~g})$ with different reagents, and the color was observed in visible light, ultraviolet (UV) light of short (254 nm), and long wavelength (365 nm) under UV chamber. Photomicrography was done using Olympus C7070 camera [11].

\section{RESULTS AND DISCUSSION}

\section{Microscopical examination of stem}

The TS of stem showed epidermis with a thick cuticle and ground parenchymatous tissue. The ground tissue contained scattered vascular bundles. The vascular bundles consisted strands of xylem and phloem. The extremities were thick and lignified. The TS of stem of $V$. roxburghii is represented in Fig. 2.

\section{Microscopical examination of powdered stem}

The stem powder was examined under microscope, and prisms of calcium oxalate, pitted xylem vessels, vascular bundles, and trichomes were observed and shown in Figs. 3-6.

\section{Preliminary phytochemical screening}

Preliminary phytochemical screening was carried out according to the standard procedures [12]. Various phytochemical tests were performed to check the presence of alkaloids, glycosides, carbohydrates, flavonoids, and tannins in the plant extracts. The results of phytochemical

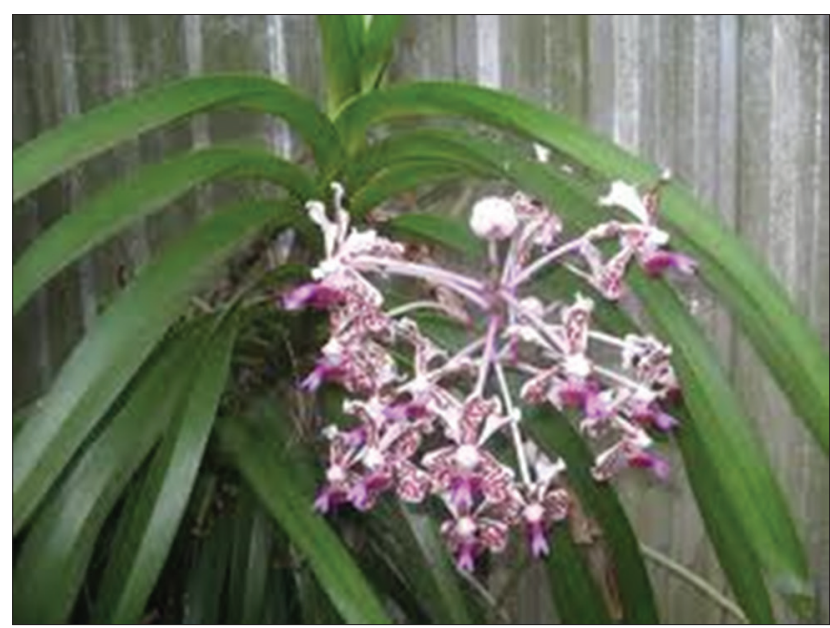

Fig. 1: Vanda roxburghii

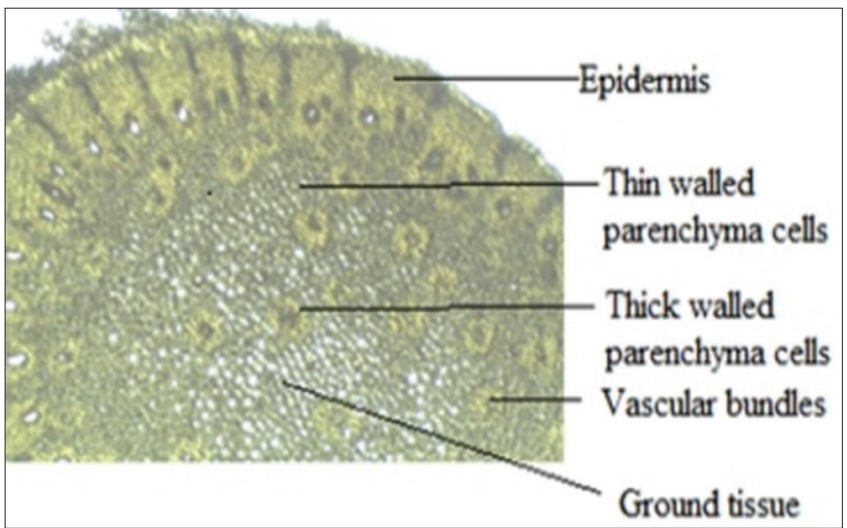

Fig. 2: T.S. Vanda roxburghii stem screening have shown the presence of various phytoconstituents such as flavonoids, carbohydrates, tannins, alkaloids, phenols, and saponins; the results are given in Table 1.

\section{Fluorescence studies of powdered drug}

The fluorescence characteristics of stem powder were studied in visible light and UV light (254 and $365 \mathrm{~nm}$ ) after treatment with various reagents. The results are represented in Table 2 [13].

\section{Physiochemical parameters}

The physicochemical parameters are mainly used to judge the purity and quality of the drug. The ash values of a drug give an idea of the earthy matter or inorganic composition or other impurities. The loss on drying at $105^{\circ} \mathrm{C}$ in stem was found to be $7.43 \pm 0.5 \%$. The total ash value was found to be $2.38 \pm 0.07 \%$, whereas the acid insoluble ash and the water-soluble ash value were found to be $0.65 \pm 0.05 \%$ and $0.62 \pm 0.04 \%$, respectively. Extractive values give an idea about the chemical composition of the drug and are also useful in the determination of exhausted or adulterated drugs. The extractive values of $V$. roxburghii petroleum ether, dichloromethane, ethanol, and water extract were found to be $1.3 \% \mathrm{w} / \mathrm{w}, 2.32 \% \mathrm{w} / \mathrm{w}, 3.32 \% \mathrm{w} / \mathrm{w}$, and $3.18 \% \mathrm{w} / \mathrm{w}$, respectively. The volatile oil content found in the powdered stems was $1.57 \% \mathrm{w} / \mathrm{w}$. The results are represented in Table 3.

\section{Extraction of phytoconstituents}

The dried stems were powdered and extracted with petroleum ether, dichloromethane, ethanol, and water in Soxhlet apparatus. The percentage yield was determined. The results are given in Table 4 .

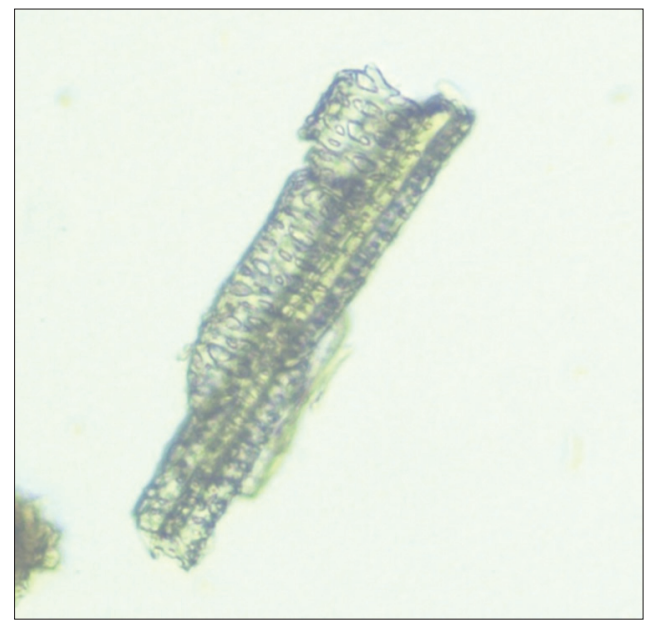

Fig. 3: Xylem vessels

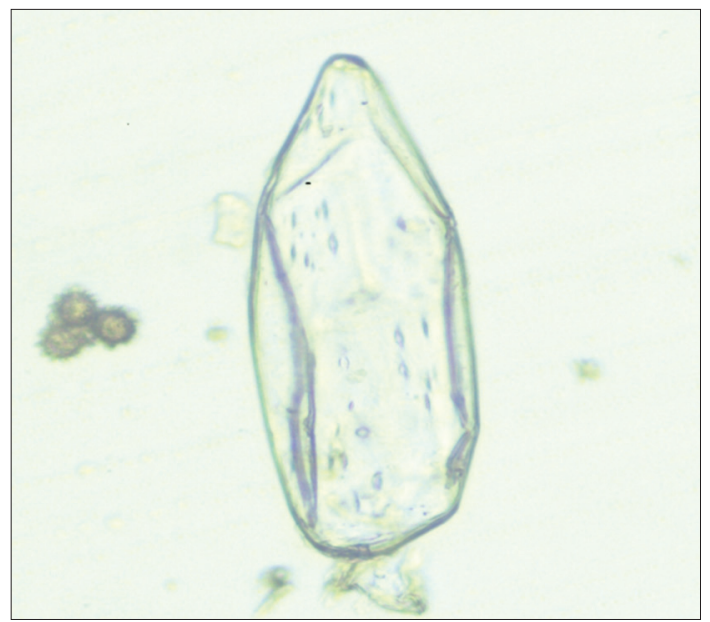

Fig. 4: Calcium oxalate crystals 
Table 1: Phytochemical screening tests of $V$. roxburghii

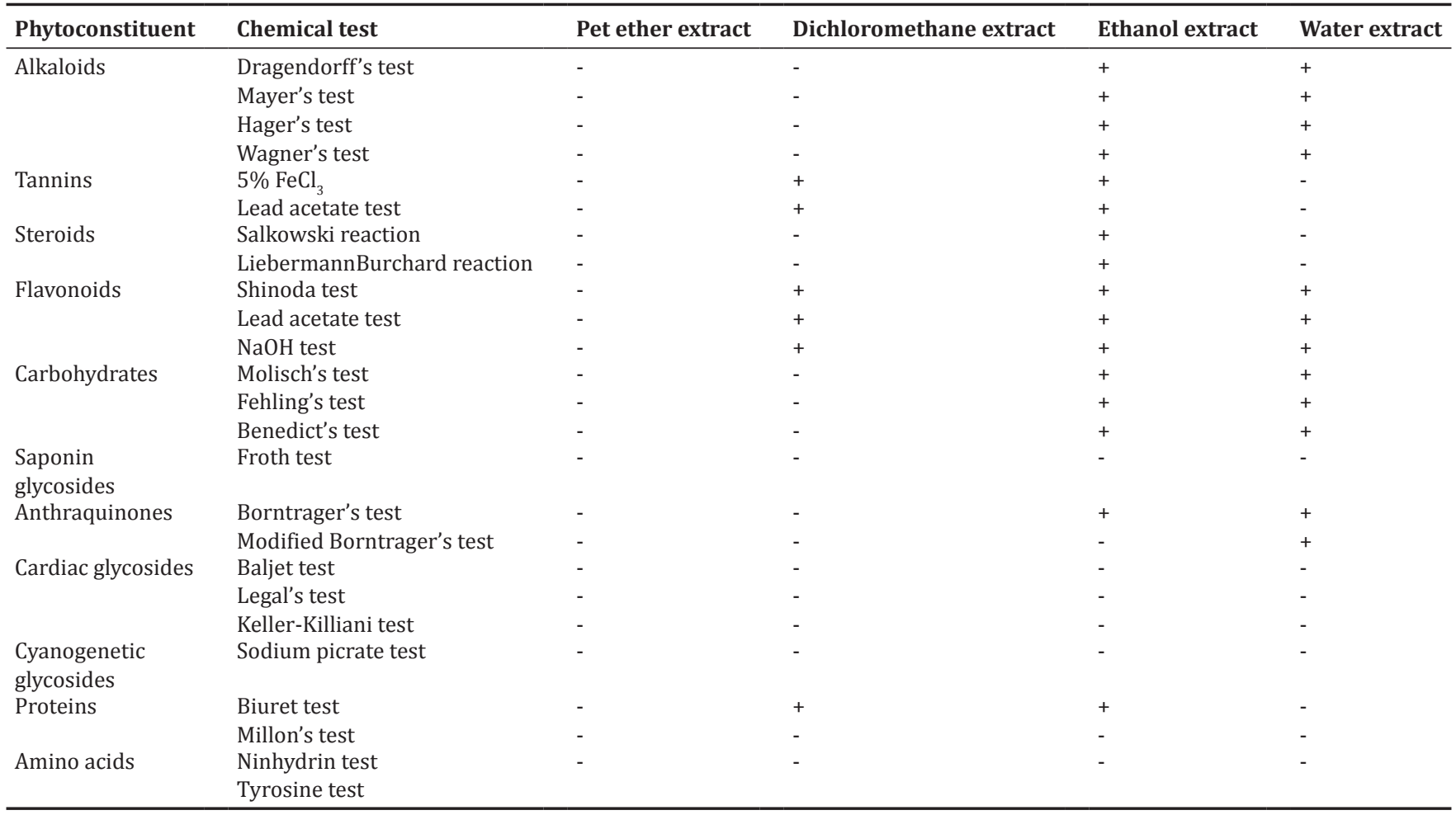

V. roxburghii: Vanda roxburghii

Table 2: Fluorescence analysis of $\mathrm{V}$. roxburghii

\begin{tabular}{|c|c|c|c|}
\hline \multirow[t]{2}{*}{ Material/treatment } & \multicolumn{3}{|c|}{ Observation under UV cabinet } \\
\hline & Visible light & Short UV 254 nm & Long UV $365 \mathrm{~nm}$ \\
\hline Drug powder as such & Greenish brown & Brown & Brown \\
\hline Powder treated with petroleum ether & Light green & Green & Green \\
\hline Powder treated with distilled water & Dark green & Dark brown & Dark brown \\
\hline Powder mounted in nitrocellulose & Greenish violet & Violet & Violet \\
\hline Powder treated with $\mathrm{NaOH}$ in methanol & Green & Dirty green & Dirty green \\
\hline Powder treated with $\mathrm{NaOH}$ in methanol and mounted in nitrocellulose & Green & Greenish violet & Violet \\
\hline
\end{tabular}

V. roxburghii: Vanda roxburghii

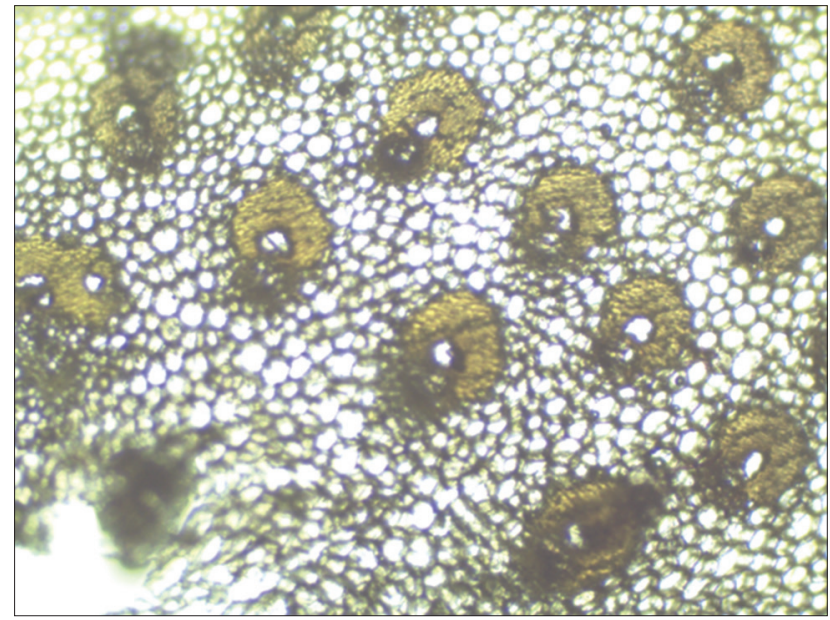

Fig. 5: Vascular bundles in the stem

\section{CONCLUSIONS}

Preliminary phytochemical screening and physicochemical investigations of $V$. roxburghii were performed in this study. These

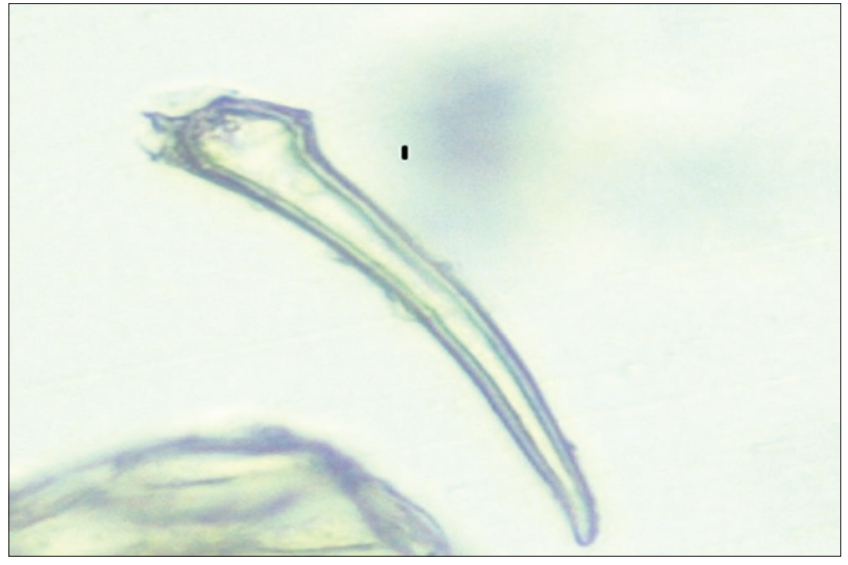

Fig. 6: Trichome

parameters are necessary for the identification of drugs and investigation of the bioactive constituents in medicinal herbs [14]. The presence of various chemical constituents in V. roxburghii may be a potential cause of treatment of various disorders. The quality of 
Table 3: Physiochemical parameters

\begin{tabular}{lllll}
\hline Parameters & Values $(\% \mathbf{w} / \mathbf{w})$ & Values $(\% \mathbf{w} / \mathbf{w})$ & Values $(\% \mathbf{w} / \mathbf{w})$ & 7.0 \\
\hline Loss on drying & 7.30 & 8.0 & 1.0 & $7.43 \pm 0.5$ \\
Content of volatile oil & 1.82 & 1.90 & 2.40 & $1.57 \pm 0.49$ \\
Total ash value & 2.44 & 2.30 & 0.66 & $2.38 \pm 0.07$ \\
Water soluble ash & 0.62 & 0.58 & $0.62 \pm 0.04$ \\
Acid insoluble ash & 0.65 & 0.60 & 0.70 \\
\hline
\end{tabular}

Table 4: Evaluation of extracts

\begin{tabular}{lll}
\hline Extract & Color of extract & Extractive value $(\% \mathbf{w} / \mathbf{w})$ \\
\hline Petroleum ether & Light green & 1.3 \\
Dichloromethane & Greenish brown & 2.32 \\
Ethanol & Dark brown & 3.32 \\
Water & Dark brown & 3.18 \\
\hline
\end{tabular}

the plant can be estimated by determining the physical parameters. These investigations are of great importance for carrying out the revalidation and estimation of its other pharmacological activities. It was concluded from the phytochemical study that the ethanolic extract contains flavonoids, glycosides, carbohydrates, and tannins which are responsible for various pharmacological activities such as anti-inflammatory, chemoprotective activity, antioxidant, antidiabetic, antianxiety, and antidepressant. The pharmacognostical standardization of the plant expresses idea about identification, physical evaluation, and monograph of plant. The present study on pharmacognostical characters of $V$. roxburghii may be helpful to supplement information with regard to identification and useful in establishing the standardization criteria.

\section{ACKNOWLEDGMENT}

The authors are thankful to the management of Shaheed Bhagat Singh College of Pharmacy, Patti, Punjab, India, for providing necessary facilities to carry out this work.

\section{REFERENCES}

1. Manjunath HM, Joshi CG, Peethamber SK. Green synthesis of silver nanoparticles using aqueous extract of Vanda tessellata leaves and its antioxidant and antibacterial activity. Res J Pharm Biol Chem Sci 2014;5:395-401.
2. Usman MR, Salgar SU, Salkar RJ, Sali LP, Jain NP, Gadgoli CH, et al. High performance thin layer chromatographic method for quantification of $\beta$ - sitosterol from Vanda roxburghii R.Br. Asian J Plant Sci Res 2012;2:524-9.

3. USDA. Floriculture Crops 2007 Summary. National Agricultural Statistics Service. New York: United States Department of Agriculture; 2008. p. 4-24.

4. Shanavaskhan AE, Sivadasan M, Alfarhan AH, Thomas J. Ethnomedicinal aspects of angiospermic epiphytes and parasites of Kerala, India. Indian J Tradit Know 2012;11:250-8.

5. Singh A, Duggal S. Medicinal orchids - An overview. Ethnobot Leaflets 2009;13:351-63.

6. Uddin MN, Afrin R, Uddin MJ, Alam AH, Rahman AA, Sadik, G. Vanda roxburghii chloroform extract as a potential source of polyphenols with antioxidant and cholinesterase inhibitory activities: Identification of a strong phenolic antioxidant. BMC Complement Altern Med 2015;15:1-9.

7. Mukhtar HM, Kalsi V. Therapeutic potential of Vanda roxburghii Roxb.: A review. Int J Curr Pharm Res 2017;8:261-5.

8. Ahmed F, Sayeed A, Islam A, Salam SM, Sadik G, Sattar MA, et al. Antimicrobial activity of extracts and a glycoside from Vanda roxburghii Br. Pak J Biol Sci 2002;5:189-91.

9. Dressler RL. Phylogeny and Classification of the Orchid Family. $1^{\text {st }}$ ed. Cambridge: University Press; 1993. p. 229.

10. Raghunathan K, Mitra R. Pharmacognosy of Indigenous Drugs. $1^{\text {st }}$ ed., Vol. 2. New Delhi: Central Council for Research in Ayurveda and Siddha; 1999. p. 853-69.

11. Prasad V, Kadam R, Deoda S, Rakesh S. Pharmacognostic, phytochemical and physiochemical studies of Mimusops elengi Linn stem bark (Sapotaceae). Pharm Lett 2012;4:607-13.

12. Harborn JB. Phytochemical Method a Guide to Modern Techniques of Plant Analysis. $3^{\text {rd }}$ ed. London, New York: Chapman and Hall; 2005. p. 41-5, 74-90, 245.

13. Prasad S, Mitra R, Ansari MS. Pharmacognostical studies on Rasna (Vanda roxburghii). J Res Indian Med 1968;2:208-20.

14. Yadav M, Chatterji S, Gupta SK, Watal G. Preliminary phytochemical screening of six medicinal plants used in traditional medicine. Int $\mathrm{J}$ Pharm Pharm Sci 2014;6:539-42. 